Research Article

\title{
Standard Heterosis for Seed and Oil Yield in Sunflower (Helianthus annuus L.)
}

\author{
Shyam Sundar Lakshman*1, Maharudra K. Godke², Jayshree Kar ${ }^{3}$ \\ ${ }^{1}$ All India Coordinated Research Project (AICRP) - Sunflower, Nimpith-743338, 24 Parganas (South), \\ West Bengal, India. Email: lakshmanshyam_ss@yahoo.co.in \\ ${ }^{2}$ Oilseed Research Station, Vasantrao Naik Marathwada Krishi Vidyapeeth (VNMPKV), Latur-413056, \\ Maharashtra, India. Email: mkghodkeors@ rediffmail.com \\ ${ }^{3}$ All India Coordinated Research Project (AICRP) - Sunflower, Odisha University of Agriculture \& \\ Technology, Bhubaneswar, Odisha-751003, India. Email: jayasreekar@ gmail.com \\ *Corresponding author
}

How to cite this paper: Lakshman, S.S., Godke, M.K. and Kar, J. (2020). Standard Heterosis for Seed and Oil Yield in Sunflower (Helianthus annus L.). Grassroots Journal of Natural Resources, 3(4): 18-27. Doi:

https://doi.org/10.33002/nr2581.6853.03042

Received: 30 June 2020

Reviewed: 17 August 2020

Provisionally Accepted: 29 September 2020

Revised: 15 October 2020

Finally Accepted: 30 October 2020

Published: 20 December 2020

Copyright $@ 2020$ by author(s)

This work is licensed under the Creative Commons Attribution International License (CC BY 4.0). http://creativecommons.org/licenses/by/4.0/
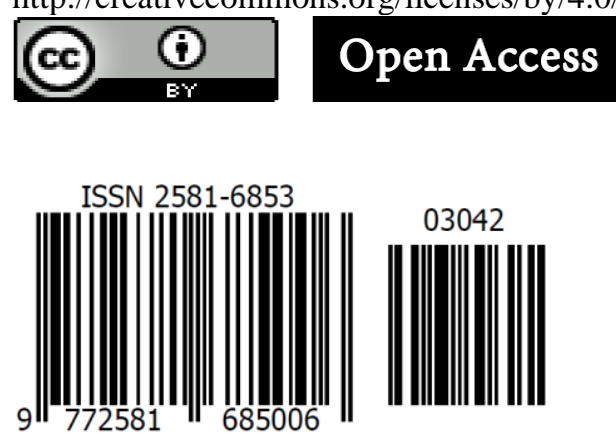

\begin{abstract}
This article is based on a study that was carried out to identify the best hybrid combinations giving high degree of useful heterosis for economic traits such as seed and oil yield in sunflower under high saline soil in coastal saline belts of West Bengal. The present study was carried out at Nimpith (West Bengal) in 2017-18 and 2018-19 with the specific objectives of identifying the standard heterotic cross combinations of sunflower hybrids and identifying the superior sunflower hybrids suitable for growing in rabi season in West Bengal's agro-climatic conditions. A set of sunflower hybrids along with the three national checks, LSFH-171, KBSH-53 and DRSH-1, were evaluated in a randomized block design. The degree of heterosis varied for important useful characters among the different crosses. Presence of high heterosis in certain crosses and low in others suggested that the nature of gene action varied with genetic architecture of the parents. From the study, it may be concluded that the sunflower hybrids viz. CMS 519A X TSG-255, CMS 148A X EC201868 and CMS 207A X R-272 may be promoted for AICRP multilocation trial or coordinated trial to evaluate their performance in Indian subcontinent. It is because of their superior traits for oil yield over the best national check sunflower hybrids in given environments.
\end{abstract}

Keywords

Standard heterosis; Oil yield; Seed yield; Sunflower 


\section{Introduction}

Sunflower (Helianthus annuus L.) is the fourth important oilseed crop in the world. It belongs to the genus Helianthus and family Asteraceae. Sunflower seeds contain $38 \%$ to $42 \%$ edible oil, which is used for culinary purposes. Sunflower oil is considered as premium oil as compared to other vegetable oils because of its light-yellow colour, flavour, high smoke point and high level of linoleic acid (55\% - 60\%). Sunflower was introduced in India in 1969 from USSR for its distinct advantages viz., photo-insensitivity, wider adaptability, short duration, better oil quality with high polyunsaturated fatty acid content (PUFA) and high seed multiplication ratio. However, it's largescale cultivation was started from 1972 onwards with the introduction of Russian varieties. In India, sunflower was cultivated over an area of 0.7 million hectares in 2014-15 (Padmaiah et al., 2015), and at present sunflower was cultivated over an area of 550,000 hectares with a production and productivity of 335,000 tons and 0.64 ton per hectare, respectively (Anonymous, 2018). It occupies an area of about 360,000 hectares with a production of 210,000 tonnes and productivity of 0.57 tons per ha in Karnataka (Anonymous, 2017). Sunflower has a huge scope of being grown in West Bengal (Dutta, 2011). In West Bengal, sunflower is one of the most important oilseed crops after rapeseed-mustard during winter season. It was grown on about 21,000 ha in rabi (winter) season during 2016-17. Due to short winter spell and delayed and heavy rainfall during rainy season, the sowing of mustard was delayed which ultimately reduced the production of rapeseed-mustard. The delayed sowing also invites the insect pests in most of the years. Sunflower being a photoperiod natural crop has wide scope to replace the rapeseed-mustard cultivation with high yield potentiality.

The main objectives of sunflower breeding programs are the development of productive hybrids $\left(F_{1}\right)$ with high seed and oil yield. Sunflower oil yield is determined as the product of seed yield per unit area and the oil percentage in grains. Therefore, consideration of both components is important when breeding for high oil yield. National sunflower hybrid (development of new hybrid) breeding programme is a continuous programme that started in India by early 1980s. Sunflower hybrid breeding was started economically in discovering CMS by Leclercq (1960) and restorer genes by Kinman (1970) and (Miller and Fick, 1997).

Exploitation of heterosis on commercial scale for a particular locality requires isolation of suitable inbred and development of hybrids. To accomplish this task, one has to know the genetic diversity of the available germplasm and the combining ability of the parents. For improving the yield potential of varieties and hybrids, the decision should be made on the choice of the right parent for hybridization. In addition to ascertaining overall specific combining ability status of cross combinations, it is also equally important to ascertain the overall heterotic status of the cross combinations across the traits.

Heterosis breeding has been commercially used in sunflower and is expected to enhance productivity further (Allard, 1960). Heterosis is the increase or decrease in vigour of $F_{1}$ over its mid or better parental value. One of the objectives of present study was to estimate the extent of heterosis for various characters and to isolate promising hybrids over standard check hybrids for seed yield and oil content for commercial exploitation. For the purpose of this study, heterosis or hybrid vigour is defined as the difference between the hybrid and the mean of the two parents (Falconer and Mackay, 1996), viz., mid-parent heterosis and better-parent heterosis, which is preferred in some circumstances, particularly in self-pollinated crops, for which the goal is to find 
a better hybrid than either of the parents. The nature and magnitude of heterosis for seed yield and its component characters is helpful in heterosis breeding. The maximum utilization of heterosis is possible when the variance due to both additive and non-additive gene actions are fully exploited since they play a significant role in determining the magnitude of expression of yield and its component.

Apart from indicating gene interaction, the measurement of heterosis over better parental value has relatively less importance than standard heterosis. Economic/standard heterosis is the superiority of $\mathrm{F}_{1} \mathrm{~s}$ over the standard check(s) or hybrid(s). Heterosis of these crops has been exploited only over the past few decades. Hybrid sunflower became a reality with the discovery of cytoplasmic male sterility and effective male fertility restoration system during 1970s. Hybrid vigour has been the main driving force for acceptance of this oilseed crop. Utilization of heterosis has allowed sunflower to become one of the major oilseeds in many countries of Eastern and Western Europe, Russia and South America and is an important crop in the USA, Australia, South Africa, China, India and Turkey. Sunflower hybrid breeding has thus played a vital role in improvement of this crop. Increasing seed and oil yield is the top priority of most sunflower breeding programmes.

\section{Standard/Economic Heterosis}

Main objectives of the estimation of economic heterosis in the present investigation was to spot out the best combination of parent giving high degree of useful heterosis for seed yield and other yield attributing character for their prospects for future use in sunflower breeding programme. Heterosis was measured as per cent increase or decrease of $F_{1}$ over standard check hybrid (standard heterosis) for all the characters. Apart from indicating gene interaction, the measurement of heterosis over better parental value has relatively less importance than standard heterosis. Therefore, it is better to measure heterosis in terms of superiority over the standard check hybrid rather than over better parent. In the present investigation the degree of heterosis varied from cross to cross for all the characters. Considerably high heterosis in certain crosses and low in the others suggested that the nature of gene action varied with the genetic architecture of the parents.

The present study was carried out with the specific objective(s) to study the standard heterosis among the newly developed sunflower hybrids for identification of the superior sunflower hybrids suitable for growing in winter season in West Bengal agro-climatic condition.

\section{Materials and Methods}

The present study was carried out at Nimpith Centre of All India Coordinated Research Project (AICRP), South 24 Parganas, West Bengal during the winter season in 2017-18 and 2018-19. The soil texture was silty clay loam and the maximum and minimum temperature varied from $18-32^{\circ} \mathrm{C}$ to $12-22^{\circ} \mathrm{C}$, respectively. Very little rainfall was received during the cropping season except the month of February in which $30-40 \mathrm{~mm}$ rainfall was received every year. This experiment was conducted during rabi season of 2017-18 and 2018-19. Experimental materials (CMS, a with respective maintainer and restorer lines) were collected from ICAR-IIOR, Hyderabad, India and other AICRP-Coordinating Centres through AICRP-System, based on their diverse origin, growth habit, phenology and adaptation. Twenty sunflower genotypes (7 CMS lines; CMS 519A, CMS38A, 207A CMS 148A, CMS 17A, P-2-7-1A and CMS 234A and 13 restorer lines like TSG- 
255, TSG-325, R-272, EC-201868, EC-601951, EC-601958, EC-602060, TSG-277, EC-625702, TSG-362, EC-625702, ID-30 and R-1-1) were grown during khrif (rainy) season in West Bengal agro-climatic condition at Nimpith during 2016-17 and 2017-18 for making hybridization in a randomized complete block design with 2 replications in a plot size of $1.8 \mathrm{~m}$ x $3.0 \mathrm{~m}$. Each plot contained three rows with spacing of $60 \mathrm{~cm} \times 30 \mathrm{~cm}$.

\section{Hybridization}

The hybridization programme was undertaken in 2017 and 2018 in kharif season at AICRPSunflower, Nimpith Centre. Hybridization was started at the onset of flowering among the parents based on flowering synchrony. The female lines used in this hybridization programme were Cytoplasmic Male Sterile lines (CMS). Pollination of selected CMS flowers were carried out by collecting pollen from heads which were already bagged prior to flowering. The bagging was done a day before over male and female flowers to prevent contamination and to avoid spilling the pollen. Pollen grains were applied by a camel hairbrush that were dipped in the pollen and gently drawn over the receptive surface of the stigmas in morning from 9 am to $11 \mathrm{am}$. The pollination was repeated for 5-6 days (in alternate days) in each of the combination to ensure sufficient seed set. After pollination, again flowers were bagged and tagged properly keeping till harvesting.

\section{Field Evaluation}

All the $\mathrm{F}_{1} \mathrm{~s}$, (15 good hybrids) were evaluated along with the three national check hybrids LSFH171, KBSH-53 and DRSH-1 in a randomized complete block design with three replications in a plot size of $3.0 \mathrm{~m}$ x $3.0 \mathrm{~m}$ in two consecutive years, 2017-18 and 2018-19 at Nimpith Centre. All the recommended agronomic practices were followed periodically for raising a good crop. The data was recorded in ten randomly selected plants from each plot of all replications on the following characters viz., days to $50 \%$ flowering, plant height at harvest $(\mathrm{cm})$, head diameter $(\mathrm{cm})$, seed weight per head (g), 100-seed weight (g), husk weight (g) and hull content (\%), volume weight (seed weight in gram per $100 \mathrm{ml}$ ) and oil content $(\%)$. The seed yield $(\mathrm{kg} / \mathrm{ha})$, and oil yield $(\mathrm{kg} / \mathrm{ha})$ were estimated on plot basis. The mean values were subjected to statistical analysis. Intrinsically, performance of the newly developed hybrids was presented as under table 1. The results on economic heterosis for seed yield ( $\mathrm{kg} / \mathrm{ha})$ and oil yield $(\mathrm{kg} / \mathrm{ha})$ for the superior hybrids were presented in table 2 and table 3.

\section{Statistical Analysis}

\section{Heterosis}

Percent increase or decrease of $F_{1}$ over the mid parent has been referred as heterosis and percent superiority of $F_{1}$ over better parent and standard check as heterobeltiosis and economic heterosis, respectively.

Heterosis, heterobeltiosis and economic heterosis will be estimated as per the methods suggested by Fonesca and Patterson (1968) and Meredith and Bridge (1972) for individual as well as over the environments. 


$$
\text { Heterosis }=\frac{\left(\overline{F_{1}}-\overline{M P}\right)}{\overline{M P}} \times 100
$$

Its significance was tested by ' $t$ ' test as follows:

$$
\begin{aligned}
& t_{E D F}=\frac{\left(\bar{F}_{1}-\overline{M P}\right)}{S E\left(\bar{F}_{1}-\overline{M P}\right)} \times 100 \\
& S E\left(\bar{F}_{1}-\overline{M P}\right)=\sqrt{\frac{2 M S E}{2 n}}
\end{aligned}
$$

Standard/Economic Heterosis

$$
\frac{\left(\overline{F_{1}}-\overline{B C}\right)}{\overline{B C}} \times 100
$$

Its significance was tested by ' $\mathrm{t}$ ' test as follows:

$$
\begin{gathered}
t_{E D F}=\frac{\left(\overline{F_{1}}-\overline{B C}\right)}{S E\left(\bar{F}_{1}-\overline{B C}\right)} \times 100 \\
E\left(\overline{F_{1}}-\overline{B C}\right)=\sqrt{\frac{2 M S E}{n}}
\end{gathered}
$$

Where, $F_{1} \quad=\quad$ Mean value of hybrid

MP $=$ Mean of two parents of corresponding $\mathrm{F}_{1}$ i.e. $\left(\mathrm{P}_{1}+\mathrm{P}_{2}\right) / 2$

$\mathrm{BP}=$ Mean value of better parent

$\mathrm{BC} \quad=\quad$ Mean value of best genotype among checks and parents

$\mathrm{n}=\quad$ Divisor in respective conditions i.e., $\mathrm{r}$ in case of individual environment and $r$ in over the environments.

$\mathrm{r}, \mathrm{s} \quad=\quad$ Number of replications and environments, respectively.

MSE $\quad=\quad$ Error mean square from (Table 3.8 and 3.9 for individual and over the environments, respectively.

tEDF $=$ Students ' $\mathrm{t}$ ' at error degrees of freedom

To calculate heterobeltiosis and economic heterosis parent and check had higher mean values were considered desirable for all the characters except traits like days to flower where lower mean was considered desirable and both were calculated in desirable directions only.

\section{Results and Discussion}

For standard/economic heterosis study, only seven cross combinations viz., CMS 519A X TSG255, PSCHT-12-38, CMS 207A X R-272, CMS 148A X EC-201868, CMS 17A X EC-601951, P2-7-1A X EC-601958, CMS 234A X R-1-1 were manifested significant positive/economic heterosis for seed and oil yield against national check hybrids (Table 2 and Table 3 ). 
Table 1: Seed Yield (kg/ha) and Oil Yield (kg/ha) of newly developed hybrids

\begin{tabular}{|l|c|c|c|c|}
\hline \multirow{2}{*}{ Hybrid combination } & \multicolumn{2}{|c|}{ Seed yield $(\mathrm{kg} / \mathrm{ha})$} & \multicolumn{2}{c|}{ Oil yield $(\mathrm{kg} / \mathrm{ha})$} \\
\cline { 2 - 5 } & $2017-18$ & $2018-19$ & $2017-18$ & $2018-19$ \\
\hline CMS 519A X TSG-255 & 2238.6 & 2025.4 & 833.7 & 766.3 \\
\hline PSCHT-12-38 & 2116.8 & 1915.2 & 769.5 & 707.3 \\
\hline CMS 207A X R-272 & 2165.1 & 1958.9 & 810.6 & 745.1 \\
\hline CMS 148A X EC-201868 & 2196.6 & 1987.4 & 800.7 & 736.0 \\
\hline CMS 17A X EC-601951 & 2003.4 & 1812.6 & 754.1 & 693.2 \\
\hline P-2-7-1A X EC-601958 & 2137.8 & 1934.2 & 751.5 & 690.8 \\
\hline CMS 234A X R-1-1 & 2028.6 & 1835.4 & 739.4 & 679.7 \\
\hline CMS 249A X EC-625702 & 1917.3 & 1734.7 & 676.1 & 621.5 \\
\hline CMS 249A X ID-30 & 1788.2 & 1617.8 & 662.4 & 608.9 \\
\hline SAHT-KH-12-18 & 1761.9 & 1594.1 & 659.7 & 606.4 \\
\hline CMS 17A X TSG-277 & 1992.9 & 1803.1 & 694.8 & 638.7 \\
\hline CMS-234A X TSG-325 & 1656.9 & 1499.1 & 615.5 & 565.8 \\
\hline CMS 17A X TSG-362 & 1531.9 & 1386.1 & 534.1 & 491.0 \\
\hline P-2-7-1A x EC-601878 & 1035.3 & 936.7 & 391.8 & 360.1 \\
\hline CMS 234A x EC-602060 & 1440.6 & 1303.4 & 542.3 & 498.5 \\
\hline KBSH-53 (C) & 2032.8 & 1839.2 & 714.5 & 656.8 \\
\hline LSFH-171 (C) & 2231.2 & 2018.8 & 699.3 & 642.8 \\
\hline DRSH-1 (C) & 1816.5 & 1643.5 & 698.0 & 641.7 \\
\hline S.Em( + ) & 62.5 & 51.6 & 20.6 & 16.7 \\
\hline C.D. at 5\% & 186.8 & 154.7 & 63.7 & 50.6 \\
\hline CV \% & 9.6 & 9.3 & 9.7 & 9.2 \\
\hline
\end{tabular}

Table 2: Seed yield and other yield attributing traits (pooled) of newly developed hybrids

\begin{tabular}{|c|c|c|c|c|c|c|c|c|c|c|c|}
\hline $\begin{array}{l}\text { Sl. } \\
\text { No. }\end{array}$ & $\begin{array}{c}\text { Hybrid Pedigree/ } \\
\text { Hybrid }\end{array}$ & \begin{tabular}{|l} 
Days \\
to $50 \%$ \\
Flow- \\
ering \\
\end{tabular} & $\begin{array}{l}\text { Plant } \\
\text { Ht. } \\
(\mathrm{cm})\end{array}$ & $\begin{array}{l}\text { Hd. } \\
\text { Dia. } \\
\text { (cm) }\end{array}$ & $\begin{array}{c}\text { Seed } \\
\text { Yield } \\
\text { (kg/ ha) }\end{array}$ & $\begin{array}{c}\text { Gr. } \\
\text { Filling } \\
\%\end{array}$ & $\begin{array}{c}100 \\
\text { Seed } \\
\text { Weight } \\
(\mathrm{g})\end{array}$ & \begin{tabular}{|c|} 
Vol. Wt. \\
(g/ 100 \\
cc)
\end{tabular} & $\begin{array}{c}\text { Hull } \\
\text { content } \\
\%\end{array}$ & $\begin{array}{l}\text { Oil } \\
\%\end{array}$ & $\begin{array}{c}\text { Oil } \\
\text { Yield } \\
\text { (kg/ } \\
\text { ha) }\end{array}$ \\
\hline 1. & $\begin{array}{c}\text { CMS 519A X } \\
\text { TSG-255 }\end{array}$ & 75.3 & 184.4 & 15.4 & 2132 & 96.0 & 5.7 & 50.3 & 30.2 & 37.6 & 801.6 \\
\hline 2. & PSCHT-12-38 & 65.3 & 180.5 & 14.7 & 2016 & 89.3 & 6.9 & 46.9 & 31.7 & 36.7 & 739.9 \\
\hline 3. & $\begin{aligned} \text { CMS 207A } & X \\
\text { R-272 } & \end{aligned}$ & 68.5 & 165.5 & 15.2 & 2062 & 94.4 & 6.2 & 50.5 & 31.4 & 37.8 & 779.4 \\
\hline 4. & $\begin{array}{c}\text { CMS 148A X } \\
\text { EC-201868 }\end{array}$ & 69.7 & 171.5 & 15.5 & 2092 & 90.0 & 6.8 & 43.7 & 35.0 & 36.8 & 769.9 \\
\hline 5. & $\begin{array}{c}\text { CMS 17A X EC- } \\
601951\end{array}$ & 70.3 & 177.9 & 15.4 & 1908 & 90.0 & 7.8 & 44.2 & 38.2 & 35.6 & 725.1 \\
\hline 6. & $\begin{array}{c}\text { P-2-7-1A X EC- } \\
601958\end{array}$ & 65.7 & 157.0 & 13.7 & 2036 & 93.0 & 5.6 & 46.8 & 31.1 & 36.8 & 722.6 \\
\hline 7. & $\begin{array}{c}\text { CMS 234A X R- } \\
1-1\end{array}$ & 69.3 & 176.8 & 15.1 & 1932 & 94.5 & 7.0 & 47.2 & 33.0 & 37.4 & 711.0 \\
\hline 8. & $\begin{array}{l}\text { CMS 249A X } \\
\text { EC-625702 }\end{array}$ & 73.3 & 204.1 & 14.9 & 1826 & 90.3 & 6.1 & 47.2 & 36.5 & 35.6 & 650.1 \\
\hline 9. & $\begin{array}{c}\text { CMS 249A X ID- } \\
30\end{array}$ & 72.0 & 192.3 & 16.0 & 1703 & 90.0 & 7.0 & 44.5 & 30.3 & 37.4 & 636.9 \\
\hline
\end{tabular}




\begin{tabular}{|l|c|c|c|c|c|c|c|c|c|c|c|}
\hline 10. & SAHT-KH-12-18 & 62.3 & 146.1 & 13.4 & 1678 & 91.7 & 6.6 & 46.7 & 29.7 & 37.8 & 634.3 \\
\hline 11. & $\begin{array}{c}\text { CMS 17A X } \\
\text { TSG-277 }\end{array}$ & 71.7 & 155.8 & 14.6 & 1898 & 88.0 & 6.0 & 42.6 & 38.3 & 35.2 & 668.1 \\
\hline $\begin{array}{l}\text { CMS-234 A X } \\
\text { TSG-325 }\end{array}$ & 62.7 & 141.9 & 13.0 & 1578 & 91.0 & 6.8 & 50.5 & 33.0 & 37.5 & 591.8 \\
\hline $\begin{array}{l}\text { 13. } \\
\text { CMS 17A X } \\
\text { TSG-362 }\end{array}$ & 71.7 & 165.3 & 14.9 & 1459 & 92.0 & 7.0 & 48.9 & 39.2 & 35.2 & 513.6 \\
\hline $14 . \quad \begin{array}{c}\text { P-2-7-1A X EC- } \\
\text { 601878 }\end{array}$ & 62.7 & 141.5 & 14.4 & 986 & 86.3 & 8.6 & 46.5 & 26.7 & 38.2 & 376.7 \\
\hline $15 . \quad \begin{array}{c}\text { CMS 234A X } \\
\text { EC-602060 }\end{array}$ & 69.0 & 161.0 & 14.0 & 1372 & 92.0 & 6.1 & 46.5 & 30.5 & 38.0 & 521.4 \\
\hline & KBSH-53 & 76.0 & 195.3 & 14.6 & 1936 & 88.7 & 4.8 & 43.2 & 37.9 & 35.5 & 687.0 \\
\hline & LSFH-171 & 77.7 & 184.2 & 14.8 & 2125 & 89.0 & 7.4 & 45.7 & 38.1 & 33.1 & 672.4 \\
\hline & DRSH-1 & 73.3 & 165.6 & 14.3 & 1730 & 91.3 & 7.5 & 47.0 & 34.5 & 38.8 & 671.2 \\
\hline
\end{tabular}

The data pertaining to seed yield and other yield attributing traits along with the check hybrids are presented in table 1 . From the pooled analysis it was observed that best cross combination coupled with good seed yield $(\mathrm{kg} / \mathrm{ha})$, high oil content and Oil yield $(\mathrm{kg} / \mathrm{ha})$ were observed in CMS 519A X TSG-255 (seed yield of $2132 \mathrm{~kg} / \mathrm{ha}, 37.6 \%$ oil and oil yield of $801.5 \mathrm{~kg} / \mathrm{ha}$ ), CMS 207A X R272 (seed yield of $2062 \mathrm{~kg} / \mathrm{ha}, 37.8 \%$ oil and oil yield of $779 \mathrm{~kg} / \mathrm{ha}$ ), CMS 148A X EC-201868 (seed yield of $2092 \mathrm{~kg} / \mathrm{ha}, 36.8 \%$ oil and oil yield of $770 \mathrm{~kg} / \mathrm{ha}$ ), PSCHT-12-38 (seed yield of 2016 $\mathrm{kg} / \mathrm{ha}$, oil content $36.7 \%$ and oil yield of $740 \mathrm{~kg} / \mathrm{ha}$ ), respectively, in comparison with the best national check hybrids LSFH-171 (seed yield of $2125 \mathrm{~kg} / \mathrm{ha}, 33.1 \%$ oil and oil yield of $672 \mathrm{~kg} / \mathrm{ha}$ ), KBSH-53 (seed yield of $1936 \mathrm{~kg} / \mathrm{ha}, 35.6 \%$ oil and oil yield of $687 \mathrm{~kg} / \mathrm{ha}$ ) and DRSH-1 (seed yield of $1730 \mathrm{~kg} / \mathrm{ha}, 38.8 \%$ oil and oil yield of $672 \mathrm{~kg} / \mathrm{ha}$ ).

Table 3: Seed yield and oil yield superiority \% over national/standard check hybrids (pooled)

\begin{tabular}{|c|c|c|c|c|c|c|c|c|}
\hline \multirow[t]{2}{*}{ Hybrid combination } & \multirow{2}{*}{$\begin{array}{c}\text { Seed } \\
\text { yield } \\
(\mathrm{kg} / \mathrm{ha})\end{array}$} & \multicolumn{3}{|c|}{ Seed yield superiority over } & \multirow{2}{*}{$\begin{array}{c}\text { Oil } \\
\text { yield } \\
\text { (kg/ha) }\end{array}$} & \multicolumn{3}{|c|}{ Oil yield superiority over } \\
\hline & & $\begin{array}{c}\text { KBSH- } \\
53\end{array}$ & $\begin{array}{l}\text { LSFH- } \\
171\end{array}$ & DRSH-1 & & $\begin{array}{l}\text { KBSH- } \\
53(\%)\end{array}$ & \begin{tabular}{|l} 
LSFH- \\
$171(\%)$
\end{tabular} & $\begin{array}{l}\text { DRSH-1 } \\
(\%)\end{array}$ \\
\hline $\begin{array}{l}\text { CMS 519A X TSG- } \\
255\end{array}$ & 2132 & 10.12 & 4.9 & 23.2 & 802 & 16.7 & 19.3 & 18.2 \\
\hline PSCHT-12-38 & 2016 & 4.13 & -0.8 & 16.5 & 740 & 7.7 & 10.1 & 9.1 \\
\hline CMS 207A X R-272 & 2062 & 6.51 & 1.5 & 19.2 & 779 & 13.4 & 15.9 & 14.9 \\
\hline $\begin{array}{c}\text { CMS 148A X EC- } \\
201868\end{array}$ & 2092 & 8.06 & 3.0 & 20.9 & 770 & 12.1 & 14.6 & 13.6 \\
\hline $\begin{array}{c}\text { CMS 17A X EC- } \\
601951\end{array}$ & 1908 & -1.45 & -6.1 & 10.3 & 725 & 5.5 & 7.9 & 6.9 \\
\hline $\begin{array}{l}\text { P-2-7-1A X EC- } \\
601958\end{array}$ & 2036 & 5.17 & 0.2 & 17.7 & 723 & 5.2 & 7.6 & 6.6 \\
\hline CMS 234A X R-1-1 & 1932 & -0.21 & -4.9 & 11.7 & 711 & 3.5 & 5.8 & 4.9 \\
\hline KBSH-53 (C) & 1936 & - & - & - & 697 & - & - & - \\
\hline LSFH-171 (C) & 2032 & - & - & - & 672 & - & - & - \\
\hline DRSH-1 (C) & 1730 & - & - & - & 678 & - & - & - \\
\hline
\end{tabular}


Across the season in Station Hybrid Trial (pooled), the highest standard heterosis for seed yield $(\mathrm{kg} / \mathrm{ha})$ was observed in sunflower hybrid CMS 519A X TSG-255 in which seed yield was recorded $10.1 \%$ higher than KBSH-53, and 23.2\% higher than DRSH-1. The significant economic/standard heterosis was also observed in sunflower hybrids viz., CMS 148A X EC201868 in which seed yield was recorded 8.06\% higher than KBSH-53, 20.9\% higher than DRSH1. Similarly, in CMS 207A X R-272 seed yield was recorded 6.51\% higher than KBSH-53, 19.2\% higher than DRSH-1. In P-2-7-1A X EC-601958, seed yield was recorded 5.2\% higher than KBSH-53 and $17.7 \%$ higher than DRSH-1.

Similarly, in Station Hybrid Trial (pooled), the highest standard heterosis for oil yield ( $\mathrm{kg} / \mathrm{ha}$ ) was observed in CMS 519A X TSG-255 in which oil yield was recorded 19.3\% higher than LSFH$171,16.4 \%$ higher than KBSH-53 and 18.2\% higher than DRSH-1. The significant economic/standard heterosis was also observed in sunflower hybrids viz., CMS 207A X R-272 in which seed yield was recorded 15.9\% higher than LSFH-171, 13.4\% higher than KBSH-53, 14.9\% higher than DRSH-1. Similarly, in CMS 148A X EC-201868, oil yield was recorded 14.6\% higher than LSFH-171, 12.1\% higher than KBSH-53, $13.6 \%$ higher than DRSH-1, whereas in PSCHT12-38 the oil yield was recorded $10.1 \%$ higher than LSFH-171, 7.7\% higher than KBSH-53, 9.1\% higher than DRSH-1.

Parameshwarappa, Jalandhar and Lingaraju (2008) and Mohansundaram, Manivannan and Vindhaiyavarman (2010) noticed the standard heterosis for seed yield and oil content. Prevalence of significant standard heterosis for seed yield has also been reported by Manivannan, Chandirakala and Abirami (2015) and Thakare et al. (2015). Higher standard heterosis for seed yield in the experimental hybrids with the use of CMS lines or tester lines were also attained by Meena, Meena and Sinha, (2013), Chandra, Ranganatha and Kumar (2015) and Supriya et al. (2017). The significant positive heterosis of hybrids based on diverse CGMS system over national check hybrid KBSH-44 was also reported by Nandini et al. (2017). The presence of significant positive heterosis among the newly developed sunflower hybrids and superiority of $H$. praecox based hybrids was also in line with studies by Tyagi et al. (2018). Standard heterosis over best check i.e., DRSH-1, for seed yield and oil content was observed by Rathi et al. (2016). The results regarding economic heterosis of diverse CMS lines based hybrids showed varied extent of magnitude and direction of heterosis for the crosses for each trait. Similar findings were reported by Tyagi, Dhillon Bajaj (2013) and Lakshman, Chakrabarty and Kole (2018).

\section{Conclusion}

In this experiment, for economic heterosis study, only seven cross combinations viz., CMS 519A X TSG-255, PSCHT-12-38, CMS 207A X R-272, CMS 148A X EC-201868, CMS 17A X EC601951, P-2-7-1A X EC-601958, CMS 234A X R-1-1 manifested significant positive/economic heterosis for oil yield (kg/ha) against national check sunflower hybrids (KBSH-53, LSFH-171 and DRSH-1). From the study it may be concluded that the sunflower hybrids viz. CMS 519A X TSG255, CMS 148A X EC-201868 and CMS 207A X R-272 may be promoted for AICRP multilocation trial or coordinated trial to evaluate further their performance in Indian subcontinent. It is recommended for their superiority for oil yield over the best national check sunflower hybrids over different environments and over the years. 


\section{Acknowledgement}

The authors are highly thankful to AICRP-Sunflower System, IIOR-ICAR Hyderabad for financial and academic support, and RAKVK, Nimpith for providing land and other necessary cooperation throughout the research programme.

\section{References}

Allard, R.W. (1960). Principles of plant breeding. New York: John Wiley and Sons Inc.

Anonymous (2017). https://www.sunflowernsa.com/stats/worldsupply.

Anonymous (2018). https://www.sunflowernsa.com/stats/worldsupply.

Chandra, B.S., Ranganatha, A.R.G. and Kumar, S. (2013). Heterosis studies for yield and it's components in sunflower hybrids over locations. Madras Agric. J., 100(13): 23-29.

Dutta A. (2011). Effects of sowing dates on yield and yield components of hybrid sunflower (H.annuus L.) in non-traditional areas of West Bengal. Journal of Crop and Weed, 7(2): 216228.

Falconer, D.S. and Mackay, T.F.C. (1996). Introduction to Quantitative Genetics, Ed 4. Harlow, Essex, UK: Longmans Green.

Fick, G.N. and Miller, J.F. (1997). Sunflower Breeding. In: A.A. Schneiter (ed.), Sunflower Technology and Production. ASA. SCSA and SSSA Monograph. No: 35. Madison, WI, USA. pp.395-440.

Fonseca, S. and Patterson, F.L. (1968). Hybrid Vigour in Seven Parent Diallel Crosses in Common Wheat (Triticum aestivum L.). Crop Science, 8: 1968.

Kinman, M.L. (1970). New Development in the USDA and State Experiment Station, Sunflower breeding programme. In: Proc. of the Fourth Int. Sunflower Conference, Memphis, Tennessa, pp.181-183.

Lakshman, S.S., Chakrabarty, N.R. and Kole, P.C. (2018). Economic Heterosis for seed and oil yield in sunflower (Helianthus annuus L.) hybrids over locations in heterosis breeding West Bengal. Indian Agriculturist, 62(1\&2): 1-8.

Leclercq, P. (1969). Line sterile cytoplasmic quechezktournesol. Ann. AmeliorPlanta, 12: 99-106.

Manivannan, N., Chandirakala, R. and Abirami, S. (2015). Evaluation of new CMS lines for heterosis breeding in sunflower (Helianthus annuus L.). Advances in Life Sciences, 5(5): 1909-1912.

Meena, C.R., Meena, H.P. and Sinha, B. (2013). Fertility restoration, combining ability effects and heterosis in sunflower (Helianthus annuus L.) using different CMS sources. Chilean J. Agric. Res., 17(99): 101-104.

Meredith, W.R. and Bridge, R.R. (1972). Heterosis and Gene Action in Cotton (G. hirsutum L.). Crop Science, 12: 304-310.

Mohansundaram, K., Manivannan, N. and Vindhaiyavarman, P. (2010). Combining ability analysis for seed yield and its components in sunflower (Helianthus annuus L.). Elec. J. Pl. Breed., 4: 864-865.

Nandini, C., Shadakshari, Y.G., Pushpa, D., Puttarangaswamy, K.T. and Kumar, V. (2017). Genetic diversity analysis in diversified CMS and restorer lines in sunflower (Helianthus annuus L.) Int. J. Curr. Microbiol. App. Sci., 6(10): 3185-3189.

Padmaiah, P., Alivelu, K., Madhuri, P., Sarada, C., Murthy, I.L.Y.N., Prasad, M.V.S., Santhalaxmi, M. and Laxmi, P. (2015). Handbook on Technology for Oilseeds Production in Andhra Pradesh. Hyderabad: ICAR- Indian Institute of Oilseed Research, pp.29-38. 
Parameshwarappa, K.G., Jalandhar, R. and Lingaraju, B.S. (2008). Heterosis and combining ability for seed yield, oil content and other agronomic traits involving mutant restorer lines in sunflower (Helianthus annuus L.). J. Oilseeds Res., 25(1): 8-12.

Rathi, S.R., Nichal, S.S., Vaidya, E.R., Ratnaparkhi, R.D. and Janjal, S.M. (2016). Combining ability for yield contributing traits and oil content in sunflower (Helianthus annuиs L.). International Journal of Tropical Agriculture, 34(4): 1043-1049.

Supriya, S.M., Kulkarni, V.V., Ranganatha, C.N. and Suresha, P.G. (2017). Quantitative Analysis of Oil Yield and Its Components in Newly Developed Hybrids of Sunflower (Helianthus annuus L.). Int. J. Curr. Microbiol. App. Sci., 6(8): 3088-3098.

Thakare, S.U., Nichal, S.S., Ingle, A.U. and Tayade, S.D. (2015). Heterosis Studies for Yield Contributing Traits and Oil Content in Sunflower (Helianthus annuus L.). Trends in Bioscience, 8(12): 3010-3017.

Tyagi, N., Dhillon, S.K. and Bajaj, R.K. (2013). Estimates of heterosis for oil content in sunflower (Helianthus annuus L.). $16^{\text {th }}$ Punjab Science Congress, p. 72.

Tyagi, V., Dhillon, S., Kaushik, P. and Kaur, G. (2018). Characterization for Drought Tolerance and Physiological Efficiency in Novel Cytoplasmic Male Sterile Sources of Sunflower (Helianthus annuus L.). Agronomy, 8: 232. 